\section{Quantification and conceptual validation of the inoculum potential of Sclerotinia sclerotiorum in soybean and bean seeds}

\author{
Sueny Kelly Santos de França ${ }^{1 *}$ (D) , Carolina da Silva Siqueira ${ }^{1}$ (D), Marina de \\ Resende Faria Guimarães ${ }^{1}$ (D), José da Cruz Machado ${ }^{1}$
}

\begin{abstract}
The fungus Sclerotinia sclerotiorum, the causal agent of white mold, is widespread throughout the world. The disease is considered to be one of the major diseases of soybean and bean crops in Brazil. The pathogen S. sclerotiorum is spread by soybean and bean seeds both in the form of sclerotia and dormant mycelium inside the seeds. The objective of this work was to evaluate the relationship between different potentials of $S$. sclerotiorum in soybean and bean seeds and the performance of these seeds, as well as to verify the localization and quantification of the inoculum of the pathogen in the seeds inoculated by Real-time PCR ( $\mathrm{PPCR}$ ), validating the term inoculum potential. Soybean and bean seeds were inoculated with the fungus by the osmotic conditioning method based on the exposure of the seeds to the fungus for periods of $24 \mathrm{~h}, 48 \mathrm{~h}, 72 \mathrm{~h}$, and $96 \mathrm{~h}$. Molecular analysis was carried out by means of qPCR in whole seeds and dissected in the integument, cotyledon and embryonic axis. The results showed that the effects of $S$. sclerotiorum on seed germination and vigor were progressive and proportional to the increases in inoculum potentials, since there was more severe damage to the seeds and consequently to the emerged plants at the highest potential (P96). The inoculum of the pathogen was found in all parts of the evaluated seeds, even at its lowest inoculum potential (P24), with an increasing DNA concentration, and the integument obtained a greater amount of DNA than the embryo, in comparison.
\end{abstract}

Index terms: seed health, seed quality, molecular detection.

RESUMO: O fungo Sclerotinia sclerotiorum, agente causal do mofo-branco, encontra-se disseminado em todo o mundo. A doença é considerada uma das principais da cultura da soja e do feijão no Brasil. O patógeno S. sclerotiorum é disseminado pelas sementes de soja e feijão tanto na forma de escleródios como na forma de micélio dormente no interior das sementes. $\mathrm{O}$ objetivo deste trabalho foi avaliar a relação entre diferentes potenciais de $S$. sclerotiorum nas sementes de soja e feijão e o desempenho dessas sementes, bem como verificar a localização e a quantificação do inóculo nas sementes inoculadas pela técnica de PCR em tempo real (qPCR), validando o termo potencial de inóculo. Sementes de soja e feijão foram inoculadas com o fungo pelo método do condicionamento osmótico baseado na exposição das sementes ao fungo pelos períodos de $24 \mathrm{~h}, 48 \mathrm{~h}, 72 \mathrm{~h}$ e $96 \mathrm{~h}$. A análise molecular foi realizada por meio de qPCR em sementes inteiras e dissecadas em tegumento, cotilédone e eixo embrionário. Os resultados demonstraram que os efeitos de S. sclerotiorum na germinação e vigor das sementes foram progressivos e proporcionais aos aumentos dos potenciais de inóculo, visto que no maior potencial (P96) foi possível observar danos mais severos nas sementes e, consequentemente, nas plantas emergidas. $O$ inóculo do patógeno foi encontrado em todas as partes das sementes avaliadas, mesmo no seu menor potencial de inóculo (P24), apresentando uma concentração de DNA crescente, onde o tegumento obteve maior quantidade de DNA que o embrião quando comparadas.

Termos para indexação: sanidade de sementes, qualidade de sementes, deteç̧ão molecular.
Journal of Seed Science, v.43, e202143022, 2021

http://dx.doi.org/10.1590/ 2317-1545v43236031

\author{
*Corresponding author: \\ E-mail: sueny.kelly@gmail.com
}

Received: 2/4/2020. Accepted: 2/7/2021.

${ }^{1}$ Universidade Federal de Lavras/ UFLA, Departamento de Fitopatologia, 37200-000 - Lavras, MG, Brasil. 


\section{INTRODUCTION}

The white mold, caused by Sclerotinia sclerotiorum (Lib.) De Bary, detected in several cultivated plant species, is spread all over the world, and it is considered as one of the most important diseases in Brazil. This pathogen causes severe and almost always irreversible damage in regions where it finds favorable climate conditions to develop. The disease is found in most soybean (Glycine max) and bean (Phaseolus vulgaris) crops in the South, Midwest, Southeast and Northeast regions (Campos et al., 2012).

In addition to its devastating nature, $S$. sclerotiorum is a fungus that associates with the seeds of its hosts in the form of sclerotia or as a dormant mycelium inside infected seeds. In this condition, some studies have demonstrated the transmission of the pathogen by soybean and bean seeds, with variable transmission rates on the basis of factors such as temperature, inoculum potential and genotypes (Zancan et al., 2015).

Owing to its epidemiological nature and the advance of the disease in the major agricultural regions of Brazil, the aforementioned pathogen has been categorized by the Ministry of Agriculture, Livestock and Supply (MAPA) as a nonquarantine pest regulated by seed certification programs for soybean, beans, cotton and sunflower (Brasil, 2009a), and the zero-tolerance standard was proposed for this pathogen in seed samples from these crops (Machado and Pozza, 2005).

Knowledge of the degree of association of pathogens with seeds is of great importance in seed health, as enables the estimation of the epidemiological model of disease development in cultivation environments, in addition to providing bases for the development of methods for detecting pathogens in seeds and formulating management strategies through treatments with different sanitary products (Schuster and Coyne, 1974; Colhoun, 1983).

For other pathosystems, it has been shown that the location of the inoculum of pathogens in different seed parts can have different consequences, especially when it colonizes seed embryos, such as reductions in germination percentage and vigor, which negatively affects the approval of seed lots (Neergaard, 1979; Dutta et al., 2016).

The objectives of this study were to describe the events that involve the interaction of S. sclerotiorum with soybean and bean seeds, taking into account the potential inoculum of the fungus in the seeds and its effects on seed quality. In addition, it also evaluated level of interaction using real-time molecular PCR detection, which has been shown to be accurate and effective at estimating the degree of association between organisms.

\section{MATERIAL AND METHODS}

Origin, maintenance of the fungal isolate and seed profile

This study used a virulent isolate from S. sclerotiorum, selected on the basis of pathogenicity tests performed in previous studies, identified as CMLAPS 242. The fungus was stored in PDA (Potato, Dextrose, Agar) and kept in the fungal culture collection of the Seed Pathology Laboratory, Universidade Federal de Lavras (UFLA).

Soybean seeds of cultivar M7110 IPRO and bean seeds of cultivar Pérola used in this experiment were previously analyzed, and they showed the following sanitary and physiological profile: no crop showed indications of the presence of S. sclerotiorum in the blotter assay for seed health testing. For bean seeds, Penicillium sp. was detected with an incidence of $21 \%$ and Aspegillus spp., with 5.5\%. For soybean seeds, there was incidence of $17.25 \%$ of Aspergillus spp., $5 \%$ of Penicillium sp. and $1.25 \%$ of Cladosporium sp. Germination rates were $91 \%$ for soybeans and $89 \%$ for beans.

\section{Isolate multiplication and inoculation of soybean and bean seeds}

The fungal isolate of $S$. sclerotiorum was multiplied in PDA culture medium with the solute mannitol adjusted to a water potential of -1.0 MPa according to the MPPS software (Michel and Radcliffe, 1995). The sterilized medium was poured into $15 \mathrm{~cm}$ Petri dishes; $5 \mathrm{~mm}$ diameter mycelial discs and pure fungal colony were added. The medium was kept in a BOD chamber with a 12-hour photoperiod at the incubation temperature of $20 \pm 2{ }^{\circ} \mathrm{C}$ for seven days.

The soybean and bean seeds were first disinfected with $1 \%$ sodium hypochlorite for thirty seconds, then washed 
in distilled water and placed to dry for 48 hours in a laboratory environment. After this period, the seeds were evenly placed on the fungal colonies and kept in contact for different periods: $24 \mathrm{~h}, 48 \mathrm{~h}, 72 \mathrm{~h}$ and $96 \mathrm{~h}$ for both cultures; such periods correspond to the inoculum potentials P24, P48, P72 and P96. Incubation took place in a BOD chamber with a temperature of $20 \pm 2{ }^{\circ} \mathrm{C}$ and $12 \mathrm{~h}$ photoperiod. For the control treatments, soybean and bean seeds were placed in the same way, for the same periods, in Petri dishes containing only the PDA medium with the solute mannitol.

Evaluation of the effects of S. sclerotiorum on the physiological and health quality of artificially inoculated and noninoculated soybean and bean seeds

Germination test: On sterilized Germitest paper, distilled and sterilized water was added at a proportion of 2.5 times the dry paper weight. Laboratory tests were performed with 200 soybean seeds and 200 bean seeds, distributed into four rolls with fifty seeds each, incubated in a germinator at $25^{\circ} \mathrm{C}$, for a period of seven days, under $100 \%$ relative humidity and continuous darkness. Assessments were carried out through visual observation of normal seedlings on the fifth and eighth days for soybeans and beans (Brasil, 2009b).

Seed Health test: This assay was conducted following the methodology used by Kawasaki and Machado (2013): 25 seeds were randomly placed in each of eight Petri dishes $(15 \mathrm{~cm}$ in diameter) containing neon medium (39 g of PDA, $150 \mathrm{mg} / \mathrm{L}$ of Bromophenol Blue, $50 \mathrm{~g}$ of chloramphenicol, $70.1 \mathrm{~g}$ of mannitol, $\mathrm{pH}$ at 4.7), in a total of 200 seeds for each treatment. The plates were incubated at $20{ }^{\circ} \mathrm{C}$ in the dark, and readings were taken at five to eight days after the start of incubation. With the aid of a stereoscopic microscope, the number of seeds contaminated with $S$. sclerotiorum in the sample was determined on the basis of the formation of typical mycelium and sclerotia and a yellow halo around the seed.

Electrical conductivity: In this vigor assay, 200 seeds were divided into four replicates of fifty seeds for each treatment, previously weighed and placed in $300 \mathrm{~mL}$ plastic cups. Then, $75 \mathrm{~mL}$ of deionized water was added to each cup, and kept for 24 hours in a BOD chamber in the dark at $25^{\circ} \mathrm{C}$. After this period, the electrical conductivity of the solution was measured through readings with the aid of a MS Tecnopon conductivity meter, and the results were expressed in $\mu \mathrm{S} . \mathrm{cm}^{-1} \cdot \mathrm{g}^{-1}$ of seeds (Krzyzanowski et al., 1999).

Emergence in soil substrate, initial and final stands and dry matter weight: To evaluate the emergence speed index (ESI), initial stand, final stand and dry matter weight of emerged plants, the vigor tests used 200 inoculated and noninoculated seeds of each crop, which were sown, by treatment, in $200 \mathrm{~mL}$ plastic cups, individually distributed into trays containing sand, soil and commercial substrate Plantimax ${ }^{\circledR}$, in a 1:1:1 ratio. Each tray contained a total of 25 cups and corresponded to a replication with a randomized block design. The experiment was carried out in a plant growth chamber, with temperature adjusted to $20 \pm 2{ }^{\circ} \mathrm{C}$ and a photoperiod of $12 \mathrm{~h}$. Daily counts of plant emergence were performed from the first seedling emergence to stand stabilization, for twelve consecutive days. Seedlings with cotyledons above ground level were considered to have emerged. Plants were kept in a growth chamber for up to 28 days after sowing. The emergence speed index was calculated according to the formula described by Maguire (1962). The initial and final stands were evaluated at five and 25 days after sowing.

Dry matter weight (DMW): Was measured at thirty days after sowing, by weighing all the plants that had emerged per replication, and these was cut $2 \mathrm{~cm}$ above the ground, in the collar region, and placed in a greenhouse with forcedair flow at a temperature of $50^{\circ} \mathrm{C}$. After 144 hours, the material was weighed on a semi-analytical balance, and the results were expressed in grams.

Quantification and localization of S. sclerotiorum in soybean and bean seeds evaluated by the real-time PCR ( $(P P C R)$ technique

DNA extraction: Was made from pure culture of Sclerotinia sclerotiorum grown for seven days in PDA culture medium with mannitol. After this period, the resulting mycelium was scraped off, macerated in a mortar with liquid nitrogen until it acquired the consistency of fine powder, and then placed in microtubes. DNA extraction from inoculated whole seeds 
was performed using 400 seeds, separately ground in an A11 Basic IKA mill containing liquid nitrogen. For seed dissection, forty seeds were used per treatment; they were kept in a wet chamber for $18 \mathrm{~h}$. After this period, with the help of a scalpel, the integument was aseptically sectioned and removed, allowing the embryo to be separated. Separated parts of seed tissues (integument and embryo) were macerated in a mortar with liquid nitrogen; then, subsamples were used for DNA extraction using Wizard ${ }^{\circledR}$ Genomic DNA Purification Kit, as per manufacturer's recommendations (Promega).

\section{Quantification of S. sclerotiorum in seed tissues by real-time PCR}

Each DNA sample was tested in duplicate with a reaction volume of $25 \mu \mathrm{L}$ per sample using the SYBR Green PCR Kit (Qiagen). For each reaction, the SYBR Green kit (Qiagen) and the methodology of Freeman et al. (2002) were used.

The values in nanograms of DNA expressed through $\mathrm{Ct}$ (Cycle Threshold) were considered for each reaction. This, in turn, is the point that detects the cycle at which the reaction has reached its exponential phase threshold, when there is accurate and reproducible fluorescence-based quantification. As a positive control, pure DNA of the target fungus was used; a standard curve with five points was established from $100 \mathrm{ng} . \mu \mathrm{L}^{-1}$ to $0.01 \mathrm{ng}$. $\mathrm{L}^{-1}$. Sterile ultrapure water was used as a negative control. Ct values were determined using the Rotor-Gene (Corbett) software, version 1.7.75. Relative efficiency was 1.13 , determined by the linear regression equation with correlation coefficient $\left(R^{2}\right)$ of 0.934 ; therefore, this was determined using the equation $Y=-3.038 X+15.53$ (Figure 1 ).

A
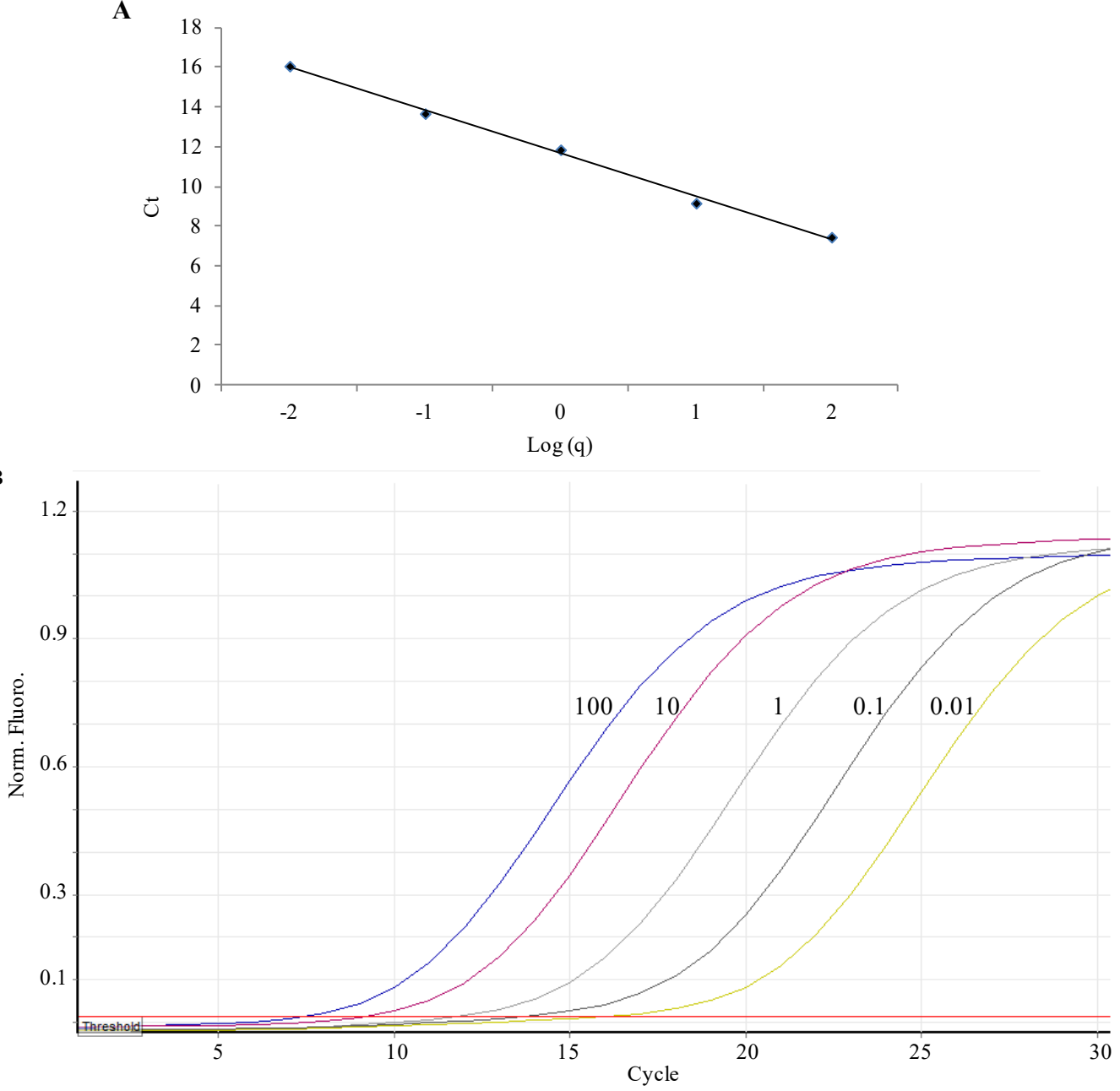

Threshold cycles $(\mathrm{Ct})$ were plotted as a function of the log dilution and as a function of fluorescence, respectively. The pathogen DNA was diluted with concentrations from $100 \mathrm{ng} \cdot \mu \mathrm{L}^{-1}$ to $0.01 \mathrm{ng} \cdot \mu \mathrm{L}^{-1}$.

Figure 1. Standard curve (A) and amplification curve (B) with serial dilution of DNA from Sclerotinia sclerotiorum. 
The experiments were carried out simultaneously, each corresponding to a completely randomized design, with two cultures (soybean and beans) and four inoculum potentials, plus the control without inoculation, in a total of two replications for each treatment.

Statistical analysis: For statistical analysis of seed quality and health data, the SISVAR ${ }^{\circledR}$ VERSION 5.3 program (Ferreira, 2011) was used. The design was completely randomized, and the means between treatments were compared by regression.

\section{RESULTS AND DISCUSSION}

\section{Effects of S. sclerotiorum on the physiological and health quality of inoculated soybean and bean seeds}

The different inoculum potentials of the fungus S. sclerotiorum in soybean and bean seeds provided significant differences for the evaluated parameters. The results showed that the fungus $S$. sclerotiorum was able to cause drastic reductions in germination and vigor because of the different inoculum potentials used.

The incidence of S. sclerotiorum in soybean and bean seeds when incubated in semi-selective medium (Neon) increased with increasing contact time of the seeds with the fungus (inoculum potential). For soybean seeds at P24, the percentage of pathogen incidence in the seeds was 40.5\%; at the potentials P48, P72 and P96, the percentages were $69 \%, 80 \%$ and $82 \%$, respectively (Figure $4 \mathrm{~A}$ ). For bean seeds, the same trend occurred; the incidence at the potential P72 was $36.5 \%$ and P96, 38.75\%; these values higher than those found at P24, that was $27.2 \%$ (Figure 4B).

In the germination test for soybean seeds, there was a reduction by $15.5 \%$ at P24, and very similar values were found at P48, with a reduction of $17.5 \%$ in comparison to P0. At the highest potentials, P72 and P96, germination was reduced by $55.5 \%$ and $67.5 \%$, respectively (Figure $2 \mathrm{~A}$ ). For bean seeds, such reduction was $8 \%$ at $\mathrm{P} 24$ and $11 \%$ at $\mathrm{P} 48$. At potentials P72 and P96, the germination values were similar, showing reductions of $16 \%$ and $19 \%$ (Figure $2 B$ ).

The electrical conductivity vigor test, which is applied to estimate cell membrane integrity, showed a proportional increase in the values of this variable as the inoculum potential increased and, consequently, membrane degradation (loss of vigor), for both soybean and bean seeds (Figures $3 \mathrm{~A}$ and $3 \mathrm{~B}$ ).

The results showed that the lowest electrical conductivity values were found at the P24 inoculum potential for soybeans and beans, with averages of 94.4 and $86.4 \mu \mathrm{S} . \mathrm{cm}^{-1} \cdot \mathrm{g}^{-1}$; while at potential P96, the means were 134.97 and $94.93 \mu \mathrm{S} . \mathrm{cm}^{-1} \cdot \mathrm{g}^{-1}$, respectively. In inoculated bean seeds, conductivity was similar at P48 and P72, on the order of 92.7 and $92.8 \mu \mathrm{S} . \mathrm{cm}^{-1} \cdot \mathrm{g}^{-1}$ (Figure $3 \mathrm{~B}$ ).
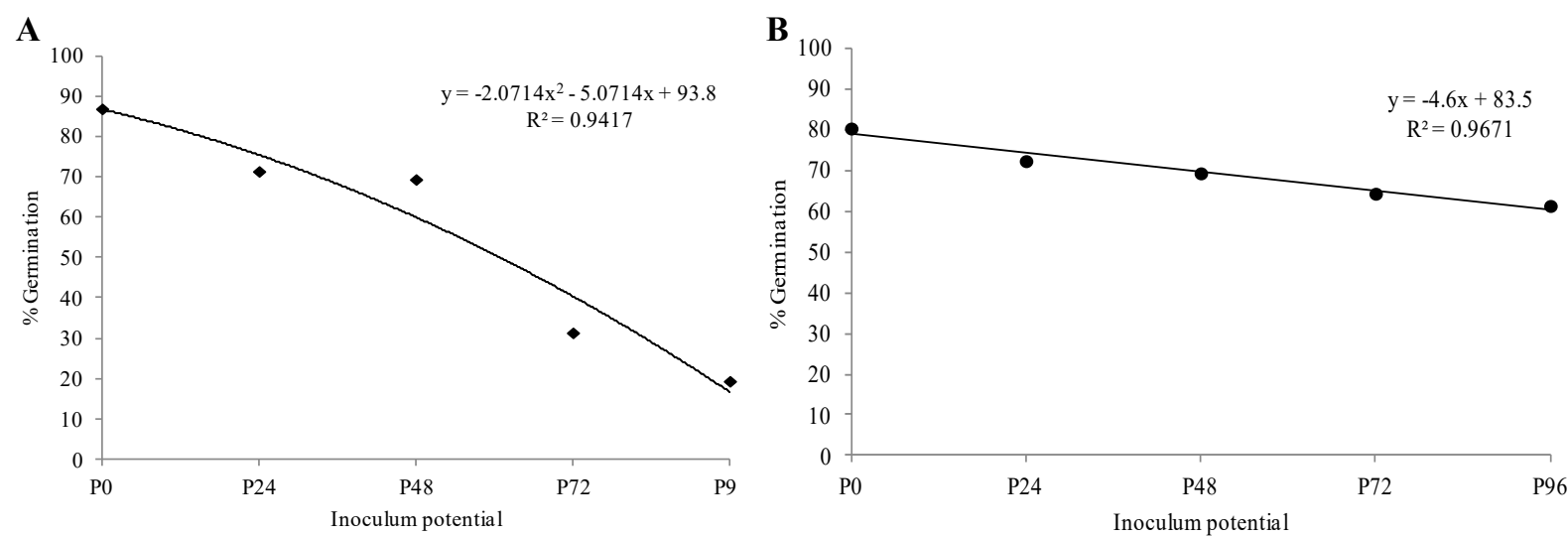

P0: no fungus; P24: 24 h; P48: 48 h; P72: 72 h; P96: 96 h.

Figure 2. Germination percentage of soybean (A) and common bean (B) seeds on the basis of the inoculum potential of Sclerotinia sclerotiorum. 

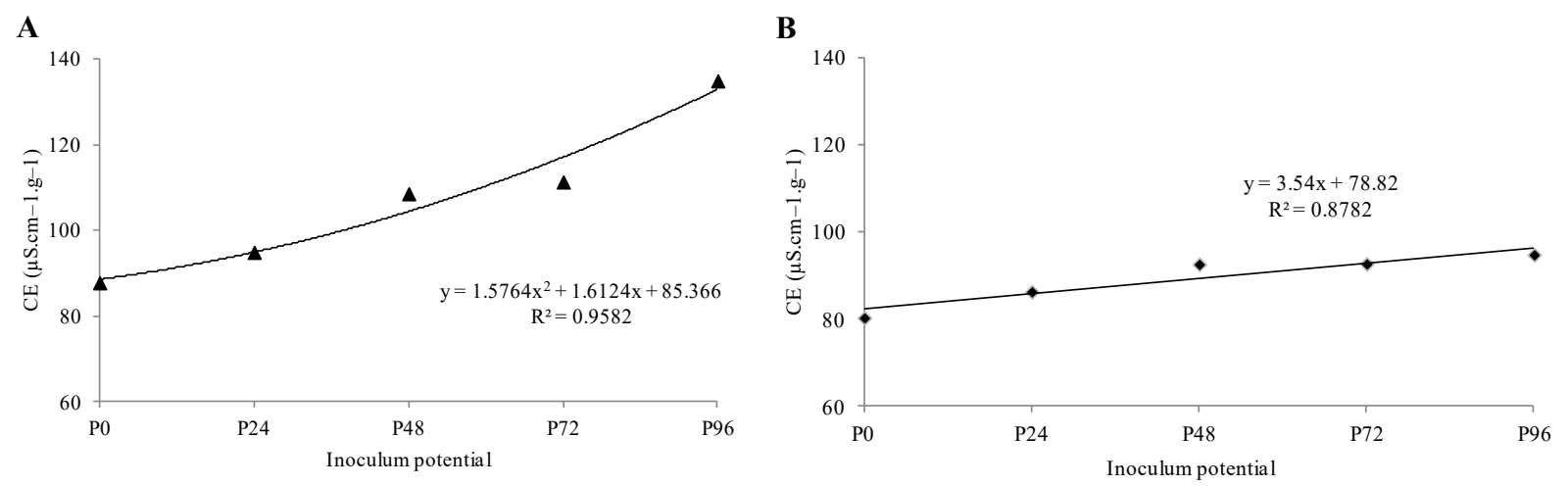

P0: no fungus; P24: 24 h; P48: 48 h; P72: 72 h; P96: 96 h.

Figure 3. Electrical conductivity of soybean (A) and bean (B) seeds inoculated with Sclerotinia sclerotiorum on the basis of the inoculum potential.

A

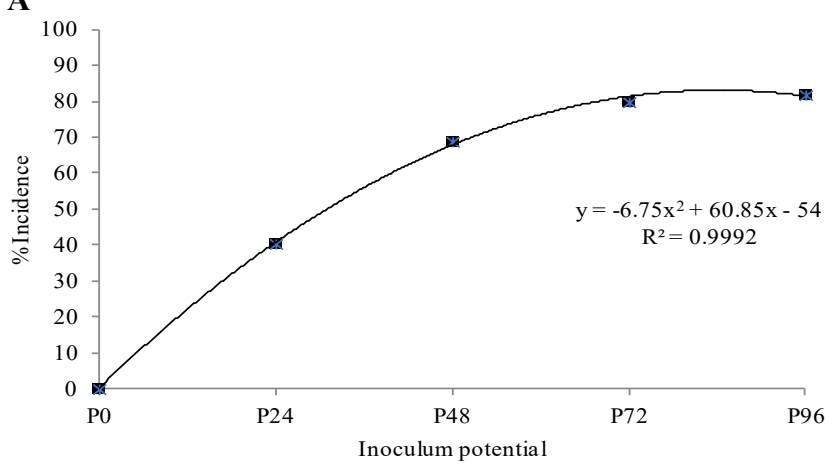

B

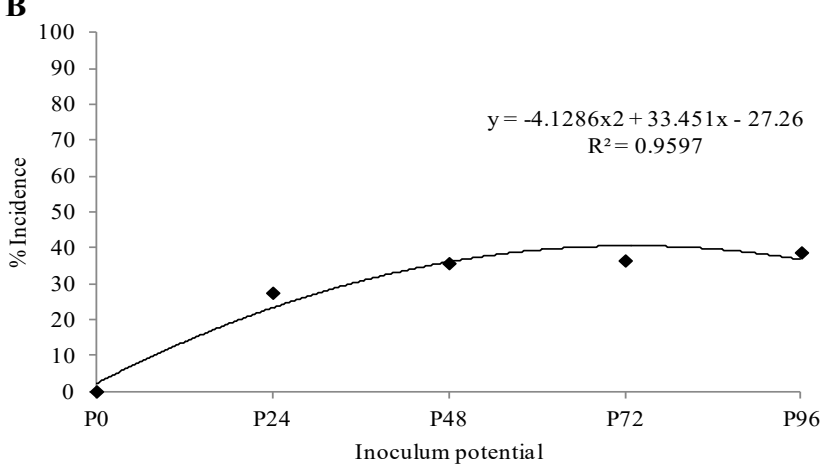

P0: no fungus; P24: 24 h; P48: 48 h; P72: 72 h; P96: 96 h.

Figure 4. Incidence of Sclerotinia sclerotiorum in soybean (A) and common bean (B) seeds under semi-selective Neon medium on the basis of the inoculum potential.

The emergence speed index was reduced as the inoculum potential increased for soybeans and beans, with the exception of the P48 potential in beans, which had a mean higher than that of P24, but it did not differ statistically. The highest indices for soybean seedlings from inoculated seeds were found at P24 with 2.08, while for bean seedlings, at P48 with 2.4, but it did not differ statistically from that of P24 (Figures 5A and 5B). The lowest indices were found at the highest inoculum potential (P96), both for soybean and bean seedlings, namely 1.61 and 0.23 , respectively. These values correspond to a reduction in the emergence speed index by approximately $55 \%$ and $91 \%$ for the corresponding crops.

The analysis of the initial and final stands and dry matter weight showed that the decrease in these variables followed a trend of decreasing value as the pathogen contact time with soybean and bean seeds increased. In the initial stand, it was found that, in inoculated seeds, at the lowest inoculum potential in soybean and beans, the highest plant emergence was $17.5 \%$ on average, and the lowest levels of emergence occurred at the highest potential (P96) with $7.5 \%$ and $4.5 \%$, respectively (Figures $6 \mathrm{~A}$ and $6 \mathrm{~B}$ ). In the final stand, the effects caused by the different inoculum potentials occurred in a similar way to that of the initial stand. 

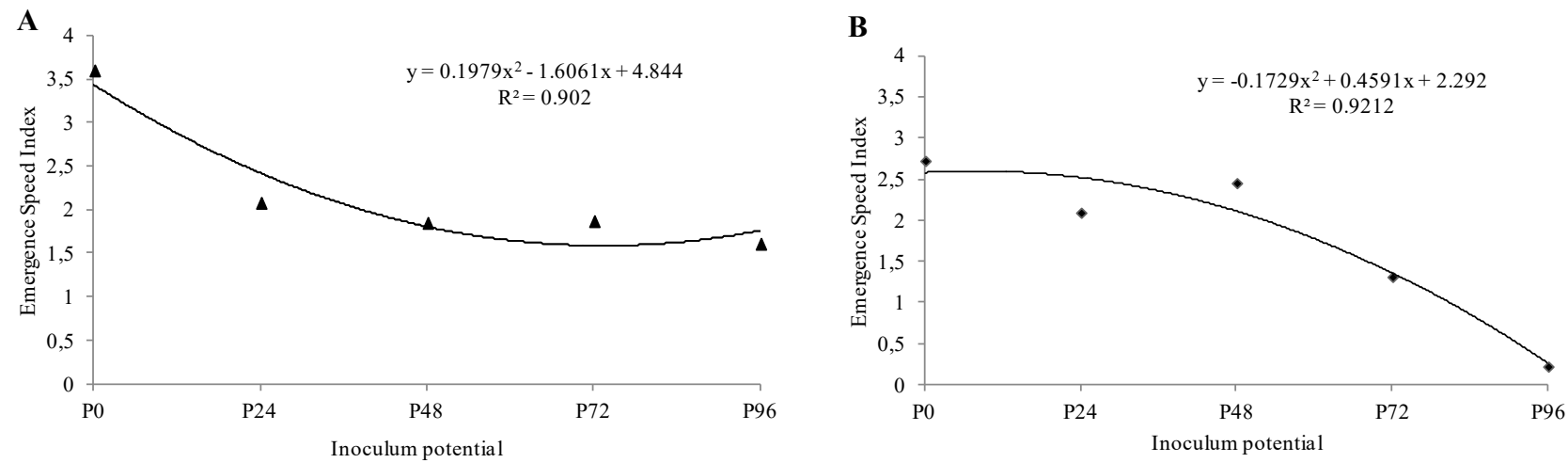

P0: no fungus; P24: 24 h; P48: 48 h; P72: 72 h; P96: 96 h.

Figure 5. Emergence Speed Index of soybean (A) and beans (B) inoculated with Sclerotinia sclerotiorum on the basis of the inoculum potential.
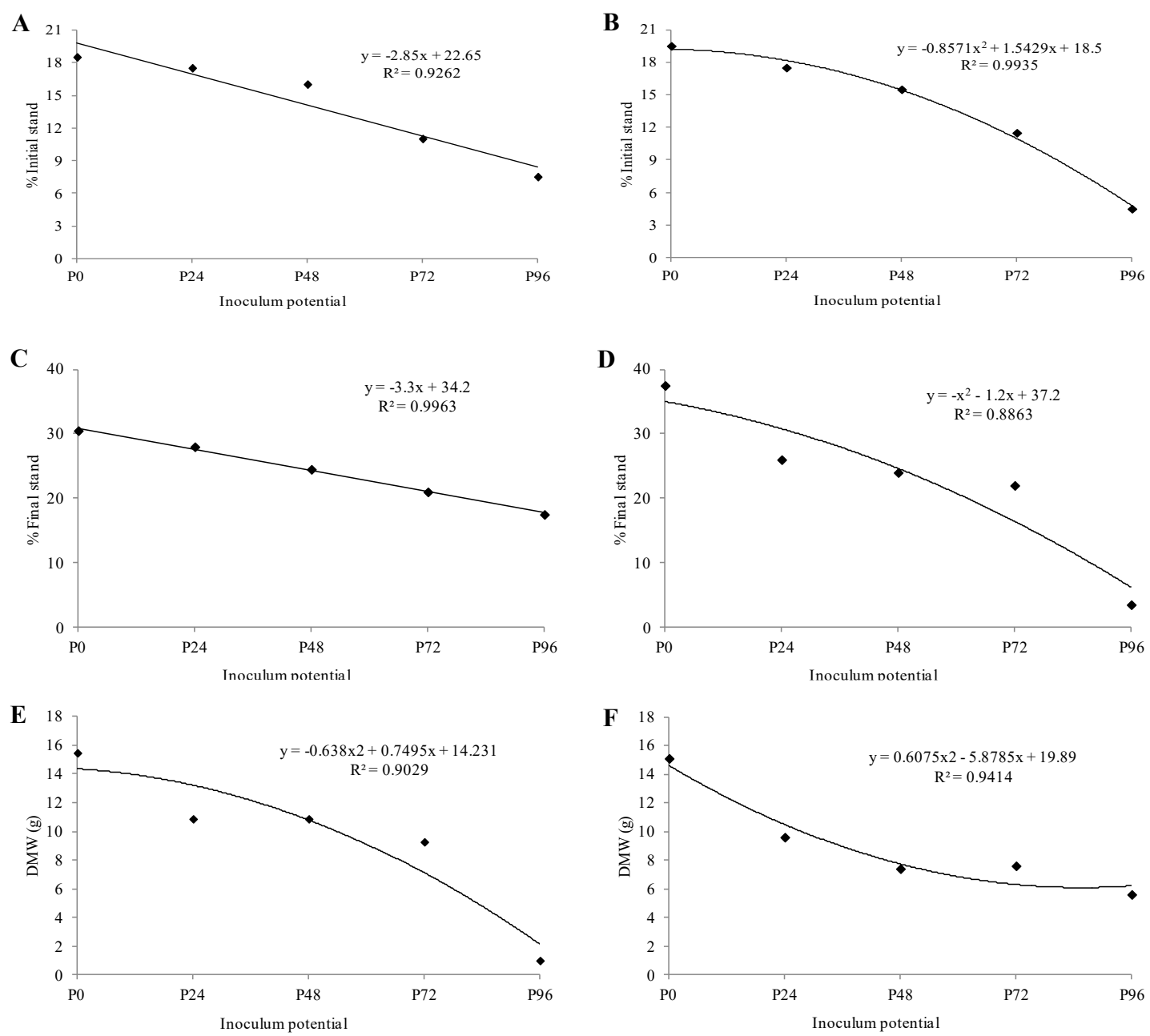

P0: no fungus; P24: 24 h; P48: 48 h; P72: 72 h; P96: 96 h.

Figure 6. Initial stand ( $A$ and $B$ ), final stand ( $C$ and $D)$ and dry matter ( $E$ and $F$ ) of soybean and bean plants, respectively, from seeds inoculated with Sclerotinia sclerotiorum at different inoculum potentials. 
As shown by the results for soybean, a greater stand of plants emerged at 28 days at $\mathrm{P} 24$ with $28 \%$, with a reduction of $8.2 \%$. The smallest emergence at P96 was $17.5 \%$, which accounts for a decrease of $42.6 \%$ in comparison to P0. In bean plants, the largest stand was similar to that of soybeans, represented by P24 with $26 \%$ emergence (this value corresponds to a decrease of $30.6 \%$ ). The lowest emergence was found at P96, with $3.5 \%$ - a drastic reduction of $90.6 \%$ in emergence (Figures $6 \mathrm{C}$ and $6 \mathrm{D}$ ).

When evaluating the effect of inoculum potentials on the dry matter of inoculated plants, there was the same trend of the other variables, i.e., the treatments that had lower inoculum potential (P24) for soybean and bean crops showed an average of $10.9 \mathrm{~g}$ and $9.6 \mathrm{~g}$, with a decrease from 28.81 to $37.3 \%$, respectively. At P96, the average was $1.03 \mathrm{~g}$ and $5.06 \mathrm{~g}$, a reduction by $93.3 \%$ and $67.16 \%$ (Figures $6 \mathrm{E}$ and $6 \mathrm{~F}$ ).

Owing to the fundamentals of seed pathology, several factors can interfere in the degree of interaction between pathogens and seeds of host species. According to the current seed health tests, the results almost always indicate only the incidence of pathogens in the analyzed samples, providing few insights into the intensity or potential of inoculum present in the host seeds.

Thus, the results of this study make it clear that the inoculum potential of S. sclerotiorum in soybean and bean seeds is an extremely important aspect, based on its negative effects on germination, health, dry matter, vigor assessed by conductivity, emergence speed index and stands.

Importantly, the interaction between S. sclerotiorum and soybean and bean seeds produced different effects between the two pathosystems. Although the time of exposure of the seeds of the two species to the fungus was the same, the values for germination, initial stand, final stand, seed dry matter and vigor and pathogen incidence varied consistently, with more severe effects on soybean seeds. For the emergence speed index, the effects were more evident in bean seeds.

The potential effects of other phytopathogenic fungi on seeds of crops of great economic importance for Brazil, such as Fusarium oxysporum f. sp. phaseoli in beans, Stenocarpella maydis in corn, S. sclerotiorum in beans and sunflower, were reported in the literature as responsible for causing severe damage to the performance of seeds when subjected to longer periods in contact with the fungus. Consequently, germination and vigor tests showed a significant reduction (Costa et al., 2003; Siqueira et al., 2014; Guimarães et al., 2017; Botelho et al., 2013; Zancan et al., 2015).

Another finding of this study is that inoculated soybean and bean seeds, when under water restriction in semiselective medium (Neon), showed progressive increases in the incidence of S. sclerotiorum, with increased inoculum potentials in the two evaluated pathosystems. In this case, fungus incidence values in the seeds evaluated by this method were proportionally higher in soybean seeds than in bean ones.

These findings confirm the results reported by Henneberg et al. (2012) and Kawasaki and Machado (2013), who generally found that this detection method for $S$. sclerotiorum is efficient and may be due to the fact that the pathogen has a greater potential for infection when artificially inoculated and is under perfect incubation conditions to develop. The method itself can be affected by the presence of contaminants, which can occur quickly, modifying the color of the substrate. However, in this hypothesis, there is a need to identify each organism so that there is no confusion with the target pathogen.

The qPCR analysis showed the presence of the pathogen associated with all parts of the seeds inoculated by the physiological conditioning technique, thus demonstrating that even the most internal parts, such as the embryo, can contain the fungal mycelium (Table 1).

For intact seeds, there was a variation in DNA concentration of $3.40 \times 10^{-3}$ (P24) at $0.17 \times 10$ (P96) nanogram (ng) for soybean and $2.30 \times 10^{-3}$ (P24) to $2.60 \times 10^{-2}$ (P96) for bean seeds, as the inoculum potential increased (Table 1). For the dissected soybean and bean seeds, the DNA concentration values for the integument were high at all potentials, in comparison to the DNA concentration values found in the embryo. In the integument, variation was $6.80 \times 10^{-4}(\mathrm{P} 24)$ to $1.06 \times 10$ (P96) in soybeans and $2.87 \times 10^{-3}$ (P24) at $2.20 \times 10^{-2}$ (P96) in beans. The amount of DNA present in bean seeds is lower than that of soybean seeds. 
Table 1. Mean values of DNA concentration (ng/ $\mu \mathrm{L})$ detected by real-time PCR in whole and dissected soybean and bean seeds at each inoculum potential.

\begin{tabular}{ccccc}
\hline \multirow{2}{*}{ Structure } & \multicolumn{3}{c}{ Soybean } \\
\cline { 2 - 4 } & $\mathrm{P} 24$ & $\mathrm{P} 48$ & $\mathrm{P} 72$ & $\mathrm{P} 96$ \\
\hline Whole seed & $3.40 \times 10^{-3}$ & $6.40 \times 10^{-3}$ & $8.40 \times 10^{-2}$ & $0.17 \times 10$ \\
Integument & $6.80 \times 10^{-4}$ & $2.24 \times 10^{-2}$ & $0.15 \times 10$ & $1.06 \times 10$ \\
Embryo & $5.70 \times 10^{-7}$ & $7.60 \times 10^{-3}$ & $0.16 \times 10^{-1}$ & $4.04 \times 10^{-1}$ \\
\hline \multicolumn{4}{c}{ Beans } \\
\hline Whole seed & $2.30 \times 10^{-3}$ & $2.80 \times 10^{-3}$ & $2.00 \times 10^{-2}$ & $2.60 \times 10^{-2}$ \\
Integument & $2.87 \times 10^{-3}$ & $5.92 \times 10^{-3}$ & $2.00 \times 10^{-2}$ & $2.20 \times 10^{-2}$ \\
Embryo & $3.44 \times 10^{-6}$ & $1.81 \times 10^{-4}$ & $4.66 \times 10^{-4}$ & $9.77 \times 10^{-4}$ \\
\hline
\end{tabular}

P24: 24 h; P48: 48 h; P72: 72 h; P96: 96 h.

The qPCR analyses performed in the treatments showed that the presence of $S$. sclerotiorum in intact soybean and bean seeds and in their respective structures, was detected even at their lowest inoculum potential. There was an increasing DNA concentration in the parts of the evaluated seeds, in which the integument had a greater amount of DNA than the embryo, in comparison.

In this case, it should be noted that because the integument occupies the outermost part of the seeds, it can establish the first contact with the pathogen. Thus, it is colonized more quickly than the embryo. Tissue colonization can also be partial, leading to a lower DNA concentration value, as assessed by qPCR.

On the other hand, one cannot rule out the interference of other factors that could also account for the lower relative values of DNA in the embryo of inoculated seeds. Anyway, the results of the molecular analysis express the high sensitivity of the qPCR technique used in this study.

According to Boland and Hall (1988), all seed parts can be colonized by S. sclerotiorum, as the fungus is able to reach the developing seed pods, thereby destroying most of them. The presence of the mycelium of $S$. sclerotiorum infecting seeds internally has also been reported by other authors, who concluded that seeds, as carriers of the fungus, can originate inoculum to infect plants and increase the amount of sclerotia present in the soil to the subsequent seasons of the year or in the same growing season (Yang et al., 1998).

The application of the qPCR technique in this study makes it evident that the interaction of $S$. sclerotiorum with soybean and bean seeds, involves the infectious process, characterized by the association of the pathogen's inoculum with living tissues of the host. Notably, with the increase in the inoculum potential, increasing amounts of DNA could be detected in the embryo, which affected the quality of the seeds by reducing germination power, vigor and stands.

\section{CONCLUSIONS}

The concept of inoculum potential applied in pathosystems involving S. sclerotiorum and soybean and bean seeds can be validated, based on the effects on inoculated seeds, with the following parameters: germination, seed vigor (electrical conductivity and emergence speed index), initial and final stands, dry matter weight and concentration of DNA in seed tissues evaluated by the qPCR technique.

The activity of $S$. sclerotiorum in association with artificially infected soybean and bean seeds drastically and progressively affects their performance. It is proportional to the inoculum potentials used in this study in both cultures, but the most evident effect was found in soybean seeds. 


\section{ACKNOWLEDGEMENTS}

To CNPQ, CAPES and FAPEMIG for their financial support; to the companies MONSOY and SEPROTEC for making the seeds available and to the seed sector of the Department of Agriculture, Universidade Federal de Lavras, for their support in some analyses.

\section{REFERENCES}

BOLAND, G.J.; HALL, R. Epidemiology of Sclerotinia stem rot of soybean in Ontario. Phytopathology, v.78, n.9, p.1241-1245, 1988. https://www.apsnet.org/publications/phytopathology/backissues/Documents/1988Articles/Phyto78n09_1241.PDF

BOTELHO, L.S.; ZANCAN, W.L.A.; MACHADO, J.C.; BARROCAS, E.N. Performance of common bean seeds infected by the fungus Sclerotinia sclerotiorum. Journal of Seed Science, v.35, n.2, p.153-160, 2013. http://www.scielo.br/pdf/jss/v35n2/03.pdf

BRASIL. Ministério da Agricultura, Pecuária e Abastecimento. Manual de análise sanitária de sementes. Ministério da Agricultura, Pecuária e Abastecimento. Secretaria de Defesa Agropecuária. Brasília: MAPA/ACS, 2009a. 202p. https://www.gov.br/agricultura/ pt-br/assuntos/insumos-agropecuarios/insumos-agricolas/sementes-e-mudas/publicacoes-sementes-e-mudas/manual-deanalise-sanitaria-de-sementes/view

BRASIL. Ministério da Agricultura, Pecuária e Abastecimento. Regras para análise de sementes. Ministério da Agricultura, Pecuária e Abastecimento. Secretaria de Defesa Agropecuária. Brasília: MAPA/ACS, 2009b. 399p. http:// https://www.gov.br/agricultura/ pt-br/assuntos/insumos-agropecuarios/arquivos-publicacoes-insumos/2946_regras_analise_sementes.pdf

CAMPOS, E.D.; SILVA, L.H.C.; SILVA, J. Avanço branco. Pelotas: Cultivar: Grandes culturas, n.153, 2012. 17p.

COLHOUN, J. Measurement of inoculum per seed and its relation to disease expression. Seed Science and Technology, v.11, p.665$671,1983$.

COSTA, M.L.N.; MACHADO, J.C.; GUIMARÃES, R.M.; POZZA, E.A.; ORIDE, D. Inoculação de Fusarium oxysporum f. sp. phaseoli em sementes de feijoeiro através de restrição hídrica. Ciência e Agrotecnologia, v.27, n.5, p.1023-1030, 2003. http://www.scielo.br/ pdf/cagro/v27n5/a08v27n5.pdf

DUTTA, B.; SCHINEIDER, R.W.; ROBERTSON, C.L.; WALCOTT, R.R. Embryo localization enhances the survival of Acidovorax citrulli in watermelon seeds. Phytopatology, v.12, p.1-9, 2016. https://apsjournals.apsnet.org/doi/full/10.1094/PHYTO-09-15-0232-R

FERREIRA, D.F. SISVAR: a computer statistical analysis system. Ciência e Agrotecnologia, v.35, n.6, p.1039-1042, 2011. http://www. scielo.br/pdf/cagro/v35n6/a01v35n6.pdf

FREEMAN, J.; WARD, E.; CALDERON, C.; MCCARTNEY, A. A polymerase chain reaction (PCR) assay for the detection of inoculum of Sclerotinia sclerotiorum. European Journal of Plant Pathology, v.108, p.877-886, 2002. https://link.springer.com/ article/10.1023/A:1021216720024

GUIMARÃES, M.R.F.; SIQUEIRA, C.S.; MACHADO, J.C.; FRANÇA, S.K.S.; GUIMARÃES, G.C. Evaluation of inoculum potential of pathogens in seeds: relation to physiological quality and DNA quantification by qPCR. Journal of Seed Science, v.39, n.3, p.224-233, 2017. http://www.scielo.br/pdf/jss/v39n3/2317-1545-jss-39-03-00224.pdf

HENNEBERG, L.; GRABICOSKI, E.M.G.; JACCOUD-FILHO, D.S.; PANOBIANCO, M. Incidência de Sclerotinia sclerotiorum em sementes de soja e sensibilidade dos testes de detecção. Pesquisa Agropecuária Brasileira, v.47, n.6, 2012. http://www.scielo.br/pdf/pab/ v47n6/47n06a05.pdf

KAWASAKI, V.H.; MACHADO, J.C. Establishment of a semi-selective method for the detection of Sclerotinia sclerotiorum in dry bean and soybean seeds. Journal of Seed Science, v.35, p.435-442, 2013. http://www.scielo.br/pdf/jss/v35n4/04.pdf

KRZYZANOWSKI, F.C.; VIEIRA, R.D.; FRANÇA-NETO, J.B. Vigor de sementes: conceitos e testes. Londrina: ABRATES, 1999.

MACHADO, J.C.; POZZA, E.A. Razões e procedimentos para o estabelecimento de padrões de tolerância a patógenos em sementes. In: ZAMBOLIM, L. (ed.). Sementes: qualidade fitossanitária. Viçosa, MG: UFV, 2005. p.219-248. 
MAGUIRE, J.D. Speed of germination-aid in selection and evaluation for seedling emergence and vigor. Crop Science, Madison, v.2, n.2, p.176-177, 1962.

MICHEL, B.E.; RADCLIFFE, D. A computer program relating solute potential to solution composition for five solutes. Agronomy Journal, v.87, n.1, p.131-136, 1995. http://agris.fao.org/agris-search/search.do?recordID=US9703344

NEERGAARD, P. Seed pathology. London: The MacMillan, v.2, 1979. 839p.

SCHUSTER, M.L.; COYNE, D.P. Survival mechanisms of phytopathogenic bacteria. Annual Review of Phytopathology, v.12, p.199221, 1974. https://www.annualreviews.org/doi/pdf/10.1146/annurev.py.12.090174.001215

SIQUEIRA, C.S.; BARROCAS, E.N.; MACHADO, J.C.; SILVA, U.A.; DIAS, I.E. Effects of Stenocarpella maydis in seeds and in the initial development of corn. Journal of Seed Science, v.36, n.1, p.79-86, 2014. http://www.scielo.br/pdf/jss/v36n2/v36n2a03.pdf

YANG, X.B.; WORKNEH, F.; LUNDEEN, P. First report of sclerotium production by Sclerotinia sclerotiorum in soil on infected soybean seeds. Plant Disease, v.82, n.2, p.264-264, 1998. https://apsjournals.apsnet.org/doi/abs/10.1094/PDIS.1998.82.2.264B

ZANCAN, W.L.A.; MACHADO, J.C.; BAUTE, N.L.; SOUSA, B.F.M. Relationship between mycelial inoculum of Sclerotinia sclerotiorum and performance of sunflower seeds under controlled conditions. Bioscience Journal, v.31, n.3, p.775-784, 2015. http://www.seer. ufu.br/index.php/biosciencejournal/article/view/26090/16463 use, distribution, and reproduction in any medium, provided the original work is properly cited. 